\title{
Trans-Atlantic relations in the Southern Cone: A common security agenda ${ }^{1}$
}

\author{
MOSES B. KHANYILE \\ Centre for Military Studies, University of Stellenbosch
}

\section{Introduction}

The countries on both shores of the South Atlantic Ocean have often looked more to the north for solutions to their socio-economic and security challenges than to their counterparts across the ocean. This approach has not only resulted in mutual neglect but has also exacerbated threat perceptions among neighbours. The establishment of the Mercusor (the Common Market of the South) and the Southern African Development Community (SADC) for the Latin American and Southern African regions respectively, signals the awareness of the commonness of challenges and the need for regional solidarity. Through these sub-regional arrangements, inter-state tensions have been reduced drastically but intra-state conflicts still pose the greatest threat to regional stability. However, both regional organisations have 'inward-looking' agendas. TransAtlantic exchanges remain peripheral and minimal. Measured in terms of trade flows, for instance, between the two continents, Africa's total exports to and imports from Latin America in 1995 were slightly over two percent of Africa's overall trade. Similarly, Latin America's trade with Africa amounted to just one percent of her overall trade value. ${ }^{2}$

This paper argues that the security arrangements in the South Atlantic Ocean have to incorporate trans-oceanic interests within the context of regional interdependence. Increased co-operation in the fight against transnational and transcontinental drug trafficking, small arms proliferation, illegal fishing activities and other security challenges that transcend states and regions could contribute towards regional stability and international peace and security. The paper further argues that the Zone for Peace and Co-operation in the South Atlantic (ZPCSA) provides a common denominator through which both the Mercusor and SADC countries can establish and enhance their security interests for mutual benefit. ${ }^{3}$ It concludes by providing a brief discussion on the involvement of the Mercusor countries in peace support operations in Africa.

1 This is an edited version of a paper "Trans-Atlantic Relations in the Southern Cone: A Common Security Agenda", presented at the Symposium on International Peace and Security: The African Experience, in commemoration of fifty years of United Nations Peacekeeping 1948 - 1998, at the South African Military Academy, Saldanha, 21-23 September 1998.

2 Stahl, H.M. "Prospects for Cooperation between SADC and Latin American Trade Blocs." Paper presented at the conference on 'Trading with Latin America: Benefits and Opportunities', Pretoria, 24-25 June 1998.

3 It is worth noting that there are only four SADC countries that form part of the ZPCSA, viz. Angola, the Democratic Republic of Congo (DRC), Namibia and South Africa. Of the four Mercusor countries, Paraguay does not form part of the ZPCSA. 


\section{The zone of peace and co-operation in the South Atlantic}

Co-operation on security between countries of Africa South of the Sahara and those of Latin America is better expressed in the form of the Zone of Peace and Co-operation in the South Atlantic (ZPCSA). Proposed by Brazil and eventually established in the mid1980 s, the Zone came out of the realisation that security, peace and stability in the South Atlantic region can be achieved only through co-operation of countries on both shores of the Atlantic Ocean. The need for the eradication of all forms of violent inter-state conflict became even more evident after the Falkland War of 1982 between Argentina and Britain over the Malvinas/ Falkland Islands. On the eastern side the Atlantic, tensions between Namibia and South Africa, and the role played by extra-regional powers in the civil war in Angola remained a great challenge to peace initiatives in the region. ${ }^{4}$ These two issues dominated the United Nations' General Assembly debate on the Zone in 1986. Measures to protect the region from militarisation, arms race, the presence of foreign military bases and nuclear weapons had to be devised. To this end, the General Assembly adopted Resolution $41 / 11$ of 27 October 1986 in terms of which the Zone was established. Namibia and South Africa only joined it in 1990 and 1994 respectively. ${ }^{5}$

The main areas of concern to the Zone were: social and economic development; the protection of the environment; the conservation of the living resources; and the peace and security in the region. The subsequent resolutions adopted by the General Assembly since resolution $43 / 23$ of 14 November 1988 to resolution $52 / 14$ of 15 January 1998 have increasingly shown that issues of development, peace and security are inter-linked to the point that the role of armed forces of the region is crucial.

\section{The role of the armed forces}

The armed forces of the member states have different, but specific, roles to play in the areas identified by the Zone.

\section{SOCIAL AND ECONOMIC DEVELOPMENT}

The countries of the Zone are connected to each other by the vast masses of oceanic waters of the Atlantic. Communication and trade among the countries of the Zone, and those outside the region, take place through the sea. This is particularly important in peacetime. In wartime, the sea provides access to territorial targets and to vital supplies on the continent that are needed to support the war effort. ${ }^{6}$ The strategic value of the South Atlantic region to other powers, especially those with global interests, makes it vulnerable to unnecessary extra-regional interference. Since none of the Zone member states can individually determine the security agenda of the region, co-operation is the

\section{United Nations General Assembly resolution 41/11 of 27 October 1986.}

The ZPCSA initially had 22 member states (three South American and 19 African): Angola, Argentina, Benin, Brazil, Cameroon, Cape Verde, Congo, Côte d'Ivoire, Equatorial Guinea, Gabon, Gambia, Ghana, Guinea, Guinea-Bissau, Liberia, Nigeria, Sao Tomé e Principe, Senegal, Sierra Leone, Togo, Uruguay, and Zaire. Namibia joined in 1990 and South Africa in 1994. See Venter. D. 1996. "South Africa, Brazil and South Atlantic Security: Towards a Zone of Peace of Cooperation in the South Atlantic", in Guimarães, S.P. (ed.) 1996. South Africa and Brazil: Risks and Opportunities in the Turmoil of Globalisation. International Relations Research Institute (IPRI), p. 33.

Bessone, R.G.D. 1979. "The Strategic Importance of the South Atlantic for the Security and Supply of the Free World", in Council for Inter-American Security and the Institute of American Relations. 1979. Free World Security and the South Atlantic: Inter-American Symposium - 1970. Washington, D.C.: Council for Inter-American Security and the Institute of American Relations, p. 19. 
key strategy. This can be achieved through harmonisation of national security policies, especially those dealing with maritime issues in the South Atlantic region.

\begin{tabular}{|l|c|c|}
\hline GROUPING & IMPORTS $(\mathbf{R m})$ & EXPORTS $(\mathbf{R m})$ \\
\hline MERCUSOR & 2444,6 & 1601,1 \\
ANDEAN & 174,2 & 416,2 \\
NAFTA & 17010,8 & 10849,6 \\
\hline
\end{tabular}

Table 1: South Africa's Trade with Latin America - $1996^{7}$

Source: The South African Yearbook of International Affairs, 1997.

To South Africa, the region requires proper protection in order to ensure a safe and a smooth flow of goods, people and other commercial activities. Like most of the littoral countries in the Zone, South Africa relies heavily on the Atlantic Ocean for imports from and exports to the Americas (see Table 1). The Southern African countries, most of which are landlocked, have commercial, cultural, political or other links with the Americas and therefore also benefit from the security of the Atlantic Ocean. It is vitally important that trade routes to these destinations be kept open and free to enable commercial maritime traffic to conduct its business without fear of danger. The navies and air forces of the Zone countries have to ensure that safety and security for international maritime traffic is guaranteed. Piracy and illegal commercial activities, especially in the high seas, remain the challenge for these naval forces. According to Sass, "[p]iracy on the high seas is an international crime and all states may and will act against it, as they are likely to do against slave trading and drug trafficking." 8 The absence of piracy and other forms of transoceanic criminal activity do not only promote the image of the region as a safe passage route, but it also enables littoral countries to conduct their commercial activities without fear. This becomes particularly important in order to enhance economic interaction among countries in the South, and to improve South-South relations.

The vast distance separating both Latin America and Africa from the largest economic blocs of the North, i.e. the European Community (EU), North American Free Trade Agreement (NAFTA) and Asia-Pacific Economic Co-operation (APEC)) makes social and economic co-operation among the countries of the Zone imperative, possibly with a view to establishing a free trade zone in the South Atlantic region. ${ }^{9}$ When South Africa took over the chairmanship of the Zone from Brazil during its fourth meeting held on 1 and 2 April 1996 in Somerset West, the South African delegation emphasised the importance of revitalised economic and commercial interaction in the region. The following aspects were to receive immediate attention: capital market development and liberalisation, co-operation in the development of infrastructure, in science and technology, in mining and mineral exploration, and also in trade and tourism. ${ }^{10}$

\footnotetext{
7 The South African Institute of International Affairs. 1997. South African Yearbook of International Affairs, 1997. Johannesburg: The South African Institute of International Affairs. Developing Nations. Johannesburg: The International Institute for International Affairs, p. 202. 


\section{ENVIRONMENT AND CONSERVATION OF LIVING RESOURCES}

The member states identified the environment as another area of great concern for the region. The resolutions adopted at the Rio Summit on Environment and Development of 14 June 1992, and the provisions of the United Nations Convention on the Law of the Sea (UNCLOS) of 10 December 1982 require some form of monitoring and enforcement capability. South Africa signed the latter convention on 2 October 1994 before it came into force on 16 November 1994. The Convention on Fishing and Conservation of the Living Resources of the High Seas, which came into force on 20 March 1966, also provided a framework for the conservation of marine resources. ${ }^{\text {I }}$ During the Zone meeting held in Somerset West, the member states emphasised the importance, in terms of the provisions of UNCLOS III, of the Agreement on the Conservation and Management of Straddling Fish Stocks and Highly Migratory Fish Stocks of 4 August 1995 for member states of the Zone. ${ }^{12}$ These multilateral arrangements to which South Africa, together with other member states of the Zone, are signatories, place a positive responsibility on the law enforcement agencies, particularly their navies, to safeguard the South Atlantic region.

Pollution and dumping of hazardous radioactive materials in the South Atlantic is another area of concern. The strategic value of the Cape route has not declined as most of the oil from the Middle East, which is bound for Europe and North America, is shipped around the Cape. ${ }^{13}$ This is despite observations by analysts, such as Morris, that "there is an inflated perception of the importance of the Cape route." According to Morris, "the only advantage of the Cape is that the maritime traffic from the Western countries can cut the corner, but if this is not possible, they can still go wide as there are at least two thousand miles between the Cape and the Antarctic ice cap." ${ }^{14}$ However, the fact remains that most ships cannot afford to go very wide and that they have to rely on South Africa and other members of the Zone for essential supplies and for safety and rescue facilities.

During the Zone meeting in 1996 the member states reiterated the importance of "safe and secure transportation through the South Atlantic of irradiated nuclear fuels, plutonium and high-level wastes." 15 In some cases, rules and regulations governing precautionary measures to be taken when transporting such hazardous materials are flouted. Most of these regulations are embodied in multi-lateral arrangements such as the London Convention on the Prevention of Dumping at Sea of Wastes and Other Matters, and the International Convention to Prevent Pollution by Ships. ${ }^{16}$ The supertankers, which carry large amounts of oil around the Cape, are usually old and lack proper maintenance. There are currently between 30 and 50 oil tankers sailing around the Cape every month. ${ }^{17}$ This increases the possibility of oil spillages with disastrous effects on

11 See United Nations, Treaty Series, vol. 559, p. 285.

12 Venter, D. 1996. Op cit., pp. 44-45.

13 Venter, D. Ibid., pp. 39-40. See also Bessone, R.G.D. 1979. Op cit., pp. 17, 25,

14 Roelofse-Campbell, Z. 1989. "Sea Power: South Africa Between Latin America and India - An Interview with Eric Morris”. Unisa Latin American Report, 5 (2), September, p. 49.

Venter, D. 1996. Op cit., p. 44.

Venter, D. 1996. Ibid., pp. 44-45.

Du Plessis, L. "The Challenge of Effective Sub-Saharan Maritime Defence", in Du Plessis, L. and Hough, M. (eds) 1998. Protecting Sub-Saharan Africa: The Military Challenge. Pretoria: Human Sciences Research Council (HSRC), p. 152. 
marine life. ${ }^{18}$ For this purpose, it is important that a well co-ordinated armed deterrent should be available to cover the region.

Poaching, especially in the high seas, where the navies of most of the member states cannot monitor and patrol, also poses a serious challenge. It was against this background that South Africa decided on 20 August 1997 to enforce its Exclusive Economic Zone $(E E Z)^{19}$ around Prince Edward Islands. The growing interest in the fishing of Petagonian Toothfish in the south Atlantic and Antarctica by the extra-regional powers poses a serious threat both in the fish industry of the region and the protection of marine resources. The South African Department of Environment and Tourism estimated that as from 1996, about US\$ 20 million worth (or 5000 tons) of Toothfish were illegally removed from around the Prince Edward Islands by foreign vessels. The Toothfish stocks of the South American countries are virtually non-existent due to poaching. ${ }^{20}$ The more capable navies of the region therefore have an extra responsibility to cover areas that fall outside their EEZs. With a $3000 \mathrm{~km}$ long coastline and an EEZ of about 4,3 million $\mathrm{km}^{2}$, including the Prince Edward Island group, South Africa has the largest naval responsibility on the African side of the Zone. On the western side of the Atlantic, these navies are Argentina, Brazil and Chile, and on the eastern side, they are Nigeria, Ghana and South Africa. At the moment the latter three only have what could be regarded as constabulary navies. ${ }^{21}$

The additional financial burden imposed on such navies restricts their ability to keep the whole region under surveillance. ${ }^{22}$ UNCLOS III, which makes provision for the establishment of the International Seabed Authority and the International Tribunal for the Law of the Sea, where the former would determine and regulate the exploitation of the seabed beyond national jurisdiction, and the latter would deal with disputes, does not cater for enough financial assistance for navies with additional responsibilities. ${ }^{23}$ Consequently, large parts of the region might remain vulnerable to poaching and disastrous leakage's from tankers carrying oil or radioactive materials. However, the approval of the South African National Defence Force's long-term arms acquisition programme by the South African cabinet in November 1998 augurs well for the region. The programme provides for the acquisition of four corvettes, three submarines and four maritime helicopters.

\section{PEACE AND SECURITY}

It is in this area where the armed forces of the region have a definite role to play. Article 4 of Resolution $41 / 11$ of 27 October 1986 calls upon all States of the region and of all other regions to:

18

19

Grove, E. 1995. "Naval Co-operation in the South Atlantic", in Mills, G. (ed.) 1995. Op cit., p. 224 .

In terms of Article 57 of the Convention of the Law of Sea, 1982, the Exclusive Economic Zone (EEZ) refers to the territorial sea extending 200 nautical miles from the base line of the country's coast. The state has sovereign rights to explore and exploit the natural resources within that area, including the seabed and its sub-soil. See Van Niekerk, H. 1995. "The United Nations Conference on the Law of the Sea 1982", in Mills, G. (ed.) 1995. Op cit., p. 102.

Statement issued by the Ministry of Environmental Affairs and Tourism on 20 August 1997.

Roelofse-Campbell, Z. 1989. Op cit., p. 49.

For a detailed discussion on the implications of unequal financial burden-sharing, see Roux, A. 1997. "The Budgetary and Welfare Consequences of Security Co-operation in the Southern Hemisphere: A South African Perspective," Scientia Militaria, Vol. 27, pp. 1-12.

Van Niekerk, H. 1995. Op cit., p. 100. 
- co-operate in the elimination of all sources of tension in the zone;

- $\quad$ respect the national unity, sovereignty, political independence and territorial integrity of every State therein;

- $\quad$ refrain from the threat or use of force;

- observe strictly the principle that the territory of a State shall not be the object of military occupation resulting from the use of force in violation of the Charter of the United Nations; and

- observe the principle that the acquisition of territories by force is inadmissible. ${ }^{24}$

This ambitious article would remain an empty commitment if it could not be pragmatised, i.e. converted into action, or enforced if any member state's activities seemed to threaten peace and security in the region. No mechanisms of intervention were put in place to cater for such situations.

The Declaration on the Denuclearisation of the South Atlantic taken by the Zone member states at its third meeting at Brasilia on 21 and 22 September 1994, and later adopted as resolutions 49/26 of December 1994 and 49/84 of 11 January 1995 by the UN General Assembly, represented a turning point in the security history of the region. According to this declaration, the whole South Atlantic region was declared a nuclear-free zone. It placed a responsibility on the member states to enforce it. It also obliges the UN to intervene in case any nuclear power, especially those outside the Zone region, deploys nuclear weapons in region. With the coming into force of the Treaty of Tlatelolco (14 February 1967) and Pelindaba Treaty (11 April 1996) which respectively declare Latin America and Caribbean, and Africa nuclear-free zones, the Zone countries do not have to deal immediately with higher-order security threats, but mainly threats associated with criminality that is affecting the region.

However, there are worrying contradictions within the ZPCSA system. The first contradiction was pointed out by President Mandela during his speech at the opening of the Fifth Session of the Independent World Commission on the Oceans held in Cape Town on 11 November 1997. While he identified the Zone as one of the mechanisms to bring about South-South co-operation in an effort to ensure economic development, peace and security in the region, he expressed his concern at "... the continuing militarisation and nuclearisation of the seas by a few naval powers." He further emphasised the fact the "international effort to demilitarise the oceans and make them nuclear-free, of which the Treaty of Pelindaba is part, must succeed." 25 If the oceans have to be free of criminal activity and dumping of hazardous wastes, there has to be credible military presence to monitor them. For this purpose, a distinction might have to be made between 'benevolent and malevolent' military presence. The latter should refer to military presence of extraregional powers acting individually or in concert with a member of the Zone in contravention of any of the resolutions of the Zone and those adopted by the UN with regard to the Zone. The former could refer to a military presence comprised of a multinational force in service of the Zone ideals.

The second contradiction is the provision in Article 1 of the Antarctic Treaty (1959) that the Antarctic area has "to be used for peaceful purposes only" and that military

24 Article 4 of the General Assembly's Resolution 41/11 of 27 October 1986.

25 Speech by President Nelson Mandela at the opening of the fifth session of the Independent World Commission on the Oceans, Cape Town, 11 November 1997. 
activity such as weapon testing is prohibited, but "military personnel and equipment may be used for scientific research or any other peaceful purposes." This provision therefore does not totally prohibit military items in the Antarctic, the bulk of which will have to pass through the Zone region, but requires that the purposes for which they are brought to the Antarctic should be peaceful. The onus is therefore on the Zone member states to determine how peaceful the intentions are of the powers which bring massive military equipment either for scientific research or peaceful purposes. Complicating matters is the advancement in technology, which might make the verification process for malevolent military intentions extremely difficult.

The other contradiction is the declared intention or the already on-going process of producing nuclear-powered ships by Argentina and Brazil. While the existing political situation in the western South Atlantic sub-region is relatively calm and is characterised by a spirit of co-operation, rather than competition, the future is unpredictable. The economic co-operation in the form of the Mercusor group can only give hope that arms race of the early 1980 s will not be repeated. It is also encouraging to note that Argentina, Brazil and South Africa have signed and ratified most of the nuclear weapons control regimes. These include the Limited/ Partial Test Ban Treaty ( 8 August 1963); the Treaty on Non-Proliferation of Nuclear Weapons (1 July 1968); the Seabed Treaty (11 February 1971) and the Comprehensive Nuclear Test Ban Treaty (10 September 1996). Of these treaties, the Comprehensive Nuclear Test Ban Treaty (CTBT) is of particular significance to the Zone region. The CTBT identifies countries with monitoring stations and laboratories that might be used to detect any nuclear explosions. Argentina and Brazil have eight and six stations respectively, while each has one laboratory. ${ }^{26}$ Despite her historically offensive-defensive posture which culminated in the manufacture of six nuclear devices in the late 1980 s, South Africa was the first country in the world "that had fully developed, and then voluntarily dismantled her military nuclear capability."27

These contradictions are particularly important especially when considering the geo-strategic value of the region, both to the individual countries inside and outside Zone, and the activities of various regional security and economic groupings. For instance, according to Bessone "[v]ery important lines of communications converge in the South Atlantic. In case of war, it would be easy to obstruct the Strait of Gibraltar and the Suez and Panama Canals. Maritime traffic through the Arctic has very severe limitations. The South Atlantic is the only maritime access-way open to the East Coast of the Americas and to Western Europe. Its control is important for the supply and security." 28 Despite these contradictions, it appears the value of security co-operation within the context of the Zone far outweighs the dangers in its absence.

Thus, a common security agenda, which could be underpinned by confidencebuilding mechanisms such as joint exercises and high-profile visits by senior political and military officials from either side of the Atlantic, will have to be designed. Joint exercises, such as ATLASUR and UNITAS could be expanded to include other SADC countries, even if using their personnel either as observers or full participants, i.e. as crews aboard South African or Latin American ships. South Africa is already participating in both of these exercises, even though as an 'invited participant' in UNITAS. The need for such an agenda among the Zone countries is not only geographic

\footnotetext{
26 Capdevila, G. 1998. "Disarmament: Treaty Targets Argentina, Brazil and Chile." Inter Press Service, 4 May.

27 Robinson, T. and Boutwell, J. 1996. "South Africa's Arms Industry: A New Era of Democratic Accountability?" Armed Forces \& Society, Vol. 22, No. 4, pp. 601-602.

Bessone, R.G.D. Op cit., p. 20.
} 
and practical but historical as well. This is demonstrated by the historical involvement of the Mercusor countries in peace support operations in Africa.

\section{Mercusor countries and peace support operations in Africa}

While no peacekeeping operations have had to be launched on the territories of the Mercusor countries, the African side of the Zone has been affected by internal strife and political instability. As Table 2 indicates, the Mercusor countries (with the exception of Paraguay) have contributed significantly to peacekeeping operations in (especially southern) Africa. It was only in UNTAG (United Nations Transition Assistance Group April 1989 to March 1990) in which only the countries from the Andean Group, Central and Caribbean were involved. ${ }^{29}$

\begin{tabular}{|c|c|c|c|c|c|c|}
\hline Operation & Location & Date & Argentina & Brazil & Uruguay & Paraguay \\
\hline ONUC & Zaire & July 60 - June 64 & $*$ & * & & \\
\hline UNAVEM I & Angola & Jan 89 - June 91 & $*$ & * & & \\
\hline UNAVEM II & Angola & June 91 - Feb 95 & * & * & & \\
\hline UNAVEM III & Angola & Feb 95 - June 97 & & * & * & \\
\hline MINURSO & $\begin{array}{l}\text { Western } \\
\text { Sahara }\end{array}$ & Sept 91 - to date & & & & \\
\hline UNUMOZ & Mozambique & $\operatorname{Dec} 92-\operatorname{Dec} 94$ & * & * & * & \\
\hline UNOSOM II & Somalia & May 93- March 95 & * & & & \\
\hline UNAMUR & $\begin{array}{l}\text { Ugandan side } \\
\text { of Rwanda/ } \\
\text { Uganda border }\end{array}$ & Oct $93-$ Mar 96 & * & & & \\
\hline UNAMIR & Rwanda & Oct $93-$ March 96 & $*$ & * & * & \\
\hline MONUA & Angola & July 97 to date & & * & * & \\
\hline
\end{tabular}

Table 2: Peace operations involving Mercusor and Africa

Key:

MINURSO - United Nations Mission for the Referendum in Western Sahara(Andean and Central

and Caribbean countries were also involved),

MONUA - United Nations Observer Mission in Angola

ONUC - United Nations Operation in the Congo

UNAMIR - United Nations Assistance Mission for Rwanda

UNAVEM - United Nations Angola Verification Mission

UNOMUR - United Nations Observer Mission Uganda-R wanda

UNOSOM - United Nations Operation in Somalia

UNUMOZ - United Nations Operation in Mozambique

\section{Conclusion}

South Africa's strategic position - being located between the Atlantic and Indian oceans - offers numerous opportunities as well as threats. The member states of the Zone recognise the strategic value of South Africa's geographic position as the 'gate-keeper' to access into South Atlantic region. This 'gate-keeping' role requires not only a strong

29 The United Nations Transition Assistance Group (UNTAG) - April 1989 to March 1990 - had members from Costa Rica, Barbados, Guyana, Jamaica, Panama, Peru, Trinidad and Tobago, but no members from the Mercusor group. 
navy on the part of South Africa, but also good co-operation and constant co-ordination with the navies of the Zone. Financial constraints, and in some cases, geopolitical maneuverings by some states in the region remain main challenges to making the Zone an effective mechanism that is designed both for confidence-building and decisive action.

With Africa having the largest number of landlocked countries in the world, the Zone provides an ideal environment in which such countries can continue to maintain and improve their links with the rich countries of the North. It should be noted that while the Zone seeks to demilitarise the South Atlantic region, it requires a strong regional military (particularly naval) capability in order to monitor the region. Piracy, illegal fishing and trafficking in drugs and small arms can be dealt with effectively if the Zone countries have adequate sea-worthy and faster patrol vessels. These, in turn, require the harmonisation and co-ordination of national (maritime) security policies. Harmonisation of policies will have to take cognisance of the unequal levels of economic development of the Zone member states and their vulnerability to maritime security challenges. Coordination could include the establishment of institutional structures to pursue security objectives and to identify each country's capacity and potential role within the Zone system. 